\title{
A REVIEW ON PLANT WITHOUT SOIL - HYDROPONICS
}

\author{
Mamta D. Sardare ${ }^{1}$, Shraddha V. Admane ${ }^{2}$ \\ ${ }^{1,2}$ Assistant Professor, MIT Academy of Engineering Alandi Pune, Maharashtra, India \\ mamtasardare@gmail.com,shraddhaadmane@gmail.com
}

\begin{abstract}
With the advent of civilization, open field/soil-based agriculture is facing some major challenges; most importantly decrease in per capita land availability. In 1960 with 3 billion population over the World, per capita land was 0.5 ha but presently, with 6 billion people it is only 0.25 ha and by 2050, it will reach at 0.16 ha. Due to rapid urbanization and industrialization as well as melting of icebergs (as an obvious impact of global warming), arable land under cultivation is further going to decrease. Again, soil fertility status has attained a saturation level, and productivity is not increasing further with increased level of fertilizer application. Besides, poor soil fertility in some of the cultivable areas, less chance of natural soil fertility build-up by microbes due to continuous cultivation, frequent drought conditions and unpredictability of climate and weather patterns, rise in temperature, river pollution, poor water management and wastage of huge amount of water, decline in ground water level, etc. are threatening food production under conventional soil-based agriculture. Under such circumstances, in near future it will become impossible to feed the entire population using open field system of agricultural production only. Naturally, soil-less culture is becoming more relevant in the present scenario, to cope-up with these challenges. In soil-less culture, plants are raised without soil. Improved space and water conserving methods of food production under soil-less culture have shown some promising results all over the World.
\end{abstract}

Index Terms: Aeroponics, hydroponics, nutriculture, open field agriculture, soil-less culture

\section{INTRODUCTION}

Soil is usually the most available growing medium for plants. It provides anchorage, nutrients, air, water, etc. for successful plant growth ${ }^{[1]}$. However, soils do pose serious limitations for plant growth too, at times. Presence of disease causing organisms and nematodes, unsuitable soil reaction, unfavorable soil compaction, poor drainage, degradation due to erosion etc. are some of them. ${ }^{[2]}$ In addition, conventional crop growing in soil (Open Field Agriculture) is somewhat difficult as it involves large space, lot of labour and large volume of water $^{[2]}$. Moreover, some places like metropolitan areas, soil is not available for crop growing at all, or in some areas, we find scarcity of fertile cultivable arable lands due to their unfavorable geographical or topographical conditions ${ }^{[2]}$. Of late, another serious problem experienced since is the difficulty to hire labour for conventional open field agriculture [3]. Under such circumstances, soil-less culture can be introduced successfully ${ }^{[3]}$.

Soil-less culture mainly refers to the techniques of Hydroponics" and Aeroponics'. The term Hydroponics' was derived from the Greek words hydro' means water and ponos' means labour ${ }^{[2]}$. It is a method of growing plants using mineral nutrient solutions, without soil ${ }^{[2]}$. Terrestrial plants may be grown with their roots in the mineral nutrient solution only or in an inert medium, such as perlite, gravel, or mineral wool. Hydroponics is the technique of growing plants in soil-less condition with their roots immersed in nutrient solution. ${ }^{[4]}$ This system helps to face the challenges of climate change and also helps in production system management for efficient utilization of natural resources and mitigating malnutrition ${ }^{[3]}$. Aeroponics' is another technique, more or less similar to hydroponics with only difference that under aeroponics plants are grown with fine drops (a mist or aerosol) of nutrient solution $^{[1]}$. In India, Hydroponics was introduced in year 1946 by an English scientist, W. J. Shalto Duglas and he established a laboratory in Kalimpong area, West Bengal. He has also written a book on Hydroponics, named as Hydroponics The Bengal System‘. Later on during 1960s and 70s, commercial hydroponics farms were developed in Abu Dhabi, Arizona, Belgium, California, Denmark, German, Holland, Iran, Italy, Japan, Russian Federation and other countries. During 1980s, many automated and computerized hydroponics farms were established around the world. Home hydroponics kits became popular during 1990s.

\section{DIFFERENT AVAILABLE TECHNIQUES FOR SOIL-LESS CULTURE}

Large numbers of hydroponic/soil-less culture techniques are available. However, following factors are considered in selecting a technique:

1. Space and other available resources

2. Expected productivity

3. Availability of suitable growing medium

4. Expected quality of the produce - colour, appearance, free from pesticides, etc. 
We can classify the techniques as follows:

\subsection{Techniques of hydroponics}

It is also known as Liquid Hydroponics' method. Plants grown in solution culture have their roots suspended directly in a nutrient solution. It can further be classified into-

i) Circulating methods (closed system)/ Continuous flow solution culture

a) Nutrient film technique (NFT)

b) Deep flow technique (DFT)

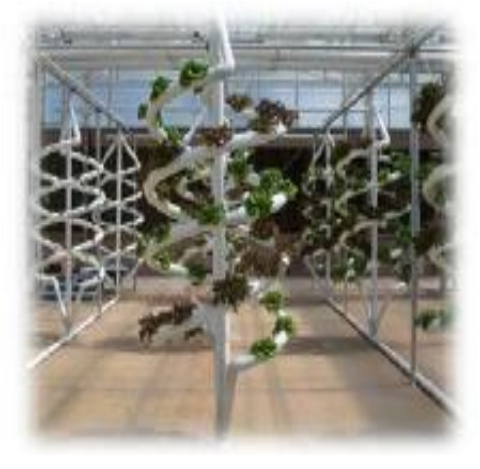

a)

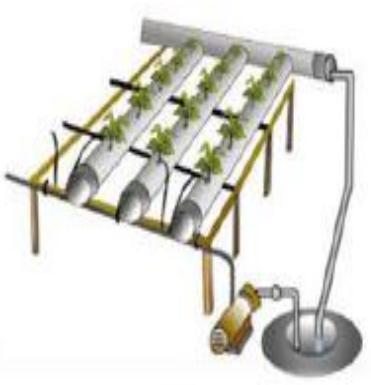

b)
Fig 1. Different circulating methods (a) Nutrient film technique, (b) Deep flow technique [4]

Flowing solution culture systems can provide a consistent nutrient environment for roots. They are highly amenable to automatic control but are subject to rapid plant desiccation if the flow of solution stops for any reason. Thus frequent attention is required.

ii) Non-circulating method (open systems)/ Static solution culture

a) Root dipping technique

b) Floating technique

c) Capillary action technique

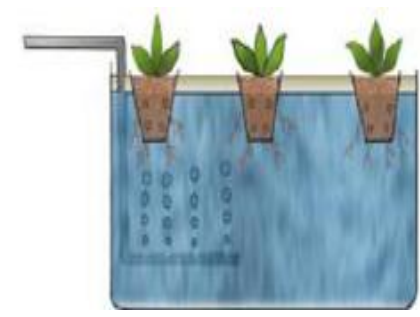

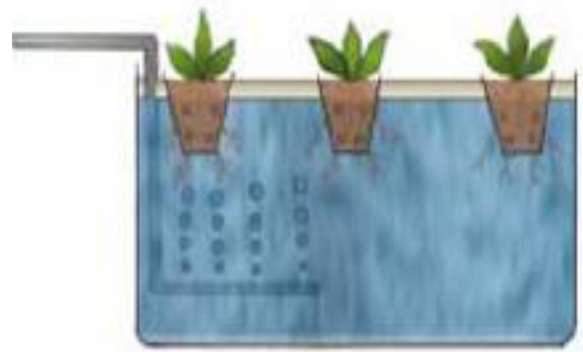

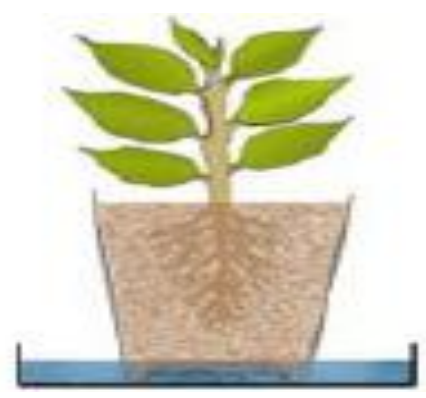

Fig 2. Different non-circulating methods (a) Root dipping technique, (b) Floating technique, (c) Capillary action technique [4]

Suitable vessels for static systems include polythene beakers, pots, glass jar and containers lined with black polythene film.

\section{B. Media culture}

The media culture method has a solid medium for the roots and is named for the type of inert medium, e.g. sand culture, gravel culture or rock wool culture. There are two main variations for each medium, sub-irrigation and top-irrigation. However, it is classified as follows:
1. Hanging bag technique
2. Grow bag technique
3. Trench or trough technique
4. Pot technique

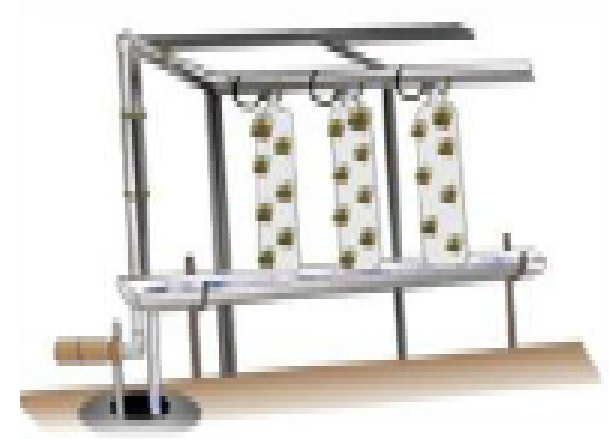

(a) 


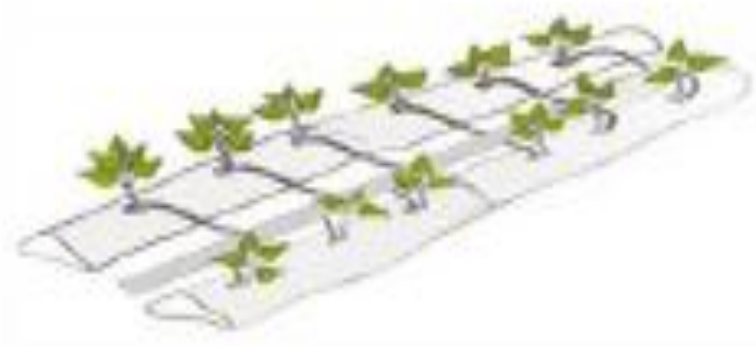

(b)

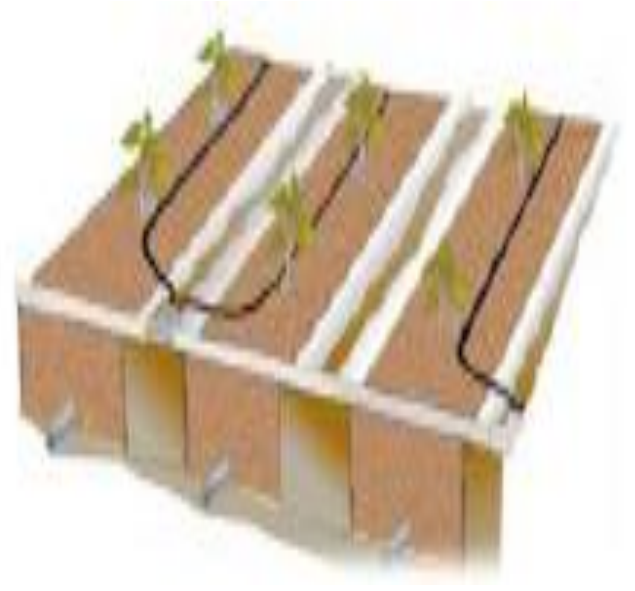

(c)

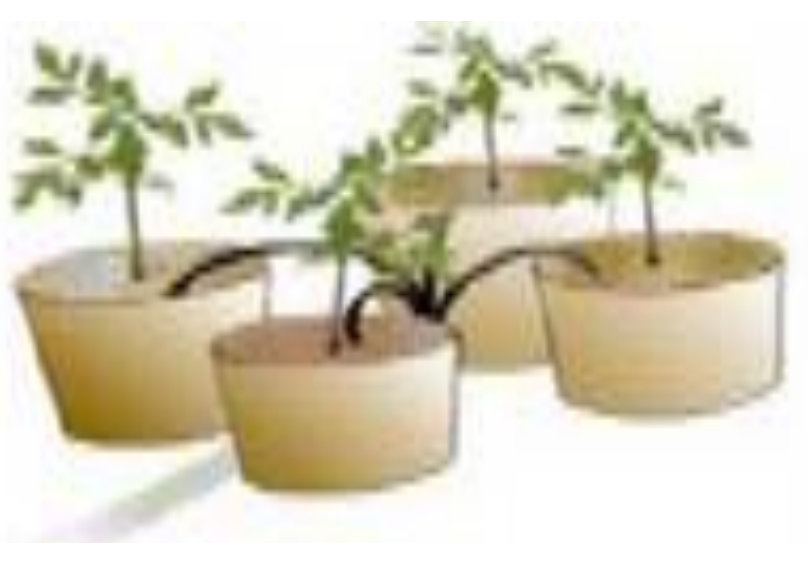

(d)

Fig 3. Different media culture method (a) Hanging bag technique, (b) Grow bag technique, (c) Trench or trough technique, (d) Pot technique [4]

\subsection{Techniques of Aeroponics}

Aeroponics is a method of growing plants where they are anchored in holes in Styrofoam panels and their roots are suspended in air beneath the panel. The aeroponics culture is usually practiced in protected structures and is suitable for low leafy vegetables like lettuce, spinach, etc. There are two techniques under this group:

1. Root mist technique

2. Fog feed technique

\subsection{List Of Crops That Can Be Grown In Soil-Less}

\section{Condition}

Everything starting from flower to fruit crops to medicinal plants can be grown using soil-less culture. List of crops are listed in Table 1, Table 2, Table 3.

Table1. List of crops that can be grown on commercial level using soil-less culture[5]

\begin{tabular}{|c|c|}
\hline Type of crops & Name of the crops \\
\hline Cereals & $\begin{array}{l}\text { Oryza sativa (Rice), Zea mays } \\
\text { (Maize) }\end{array}$ \\
\hline Fruits & Fragaria ananassa (Strawberry) \\
\hline Vegetables & $\begin{array}{l}\text { Lycopersicon esculentum (Tomato), } \\
\text { Capsicum frutescens (Chilli), } \\
\text { Solanum melongena (Brinjal), } \\
\text { Phaseolus vulgaris (Green bean), } \\
\text { Beta vulgaris (Beet), Psophocarpus } \\
\text { tetragonolobus (Winged bean), } \\
\text { Capsicum annum (Bell pepper), } \\
\text { Brassica oleracea var. capitata } \\
\text { (Cabbage), Brassica oleracea var. } \\
\text { botrytis (Cauliflower), Cucumis } \\
\text { sativus (Cucumbers), Cucumis melo } \\
\text { (Melons), Raphanus sativus } \\
\text { (Radish), Allium cepa (Onion) }\end{array}$ \\
\hline Leafy vegetables & $\begin{array}{l}\text { Lactuca sativa (Lettuce), Ipomoea } \\
\text { aquatica (Kang Kong) }\end{array}$ \\
\hline Condiments & $\begin{array}{l}\text { Petroselinum crispum (Parsley), } \\
\text { Mentha spicata (Mint), Ocimum } \\
\text { basilicum (Sweet basil), Origanum } \\
\text { vulgare (Oregano) }\end{array}$ \\
\hline $\begin{array}{l}\text { Flower / Ornamental } \\
\text { crops }\end{array}$ & $\begin{array}{l}\text { Tagetes patula (Marigold), Rosa } \\
\text { berberifolia (Roses), Dianthus } \\
\text { caryophyllus (Carnations), } \\
\text { Chrysanthemum indicum } \\
\text { (Chrysanthemum) }\end{array}$ \\
\hline Medicinal crops & $\begin{array}{l}\text { Aloe vera (Indian Aloe), } \\
\text { Solenostemon scutellarioides } \\
\text { (Coleus) }\end{array}$ \\
\hline Fodder crops & $\begin{array}{l}\text { Sorghum bicolor (Sorghum), } \\
\text { Medicago sativa (Alphalfa), } \\
\text { Hordeum vulgare (Barley), } \\
\text { Cynodon dactylon (Bermuda grass), } \\
\text { Axonopus compressus (Carpet } \\
\text { grass) }\end{array}$ \\
\hline
\end{tabular}


Table -2: Hydroponic averages compared with ordinary soil yields [5]

\begin{tabular}{|l|l|l|}
\hline $\begin{array}{l}\text { Name of } \\
\text { crop }\end{array}$ & $\begin{array}{l}\text { Hydroponic } \\
\text { equivalent per acre }\end{array}$ & $\begin{array}{l}\text { Agricultural } \\
\text { average per acre }\end{array}$ \\
\hline Wheat & $5,000 \mathrm{lb}$. & $600 \mathrm{lb}$. \\
\hline Oats & $3,000 \mathrm{lb}$. & $850 \mathrm{lb}$. \\
\hline Rice & $12,000 \mathrm{lb}$. & $750-900 \mathrm{lb}$. \\
\hline Maize & $8,000 \mathrm{lb}$. & $1,500 \mathrm{lb}$. \\
\hline Soybean & $1,500 \mathrm{lb}$. & $600 \mathrm{lb}$. \\
\hline Potato & 70 tons & 8 tons lb. \\
\hline Beet root & $20,000 \mathrm{lb}$. & $9,000 \mathrm{lb}$. \\
\hline Cabbage & $18,000 \mathrm{lb}$. & $13,000 \mathrm{lb}$. \\
\hline Peas & $14,000 \mathrm{lb}$. & $2,000 \mathrm{lb}$. \\
\hline Tomato & 180 tonnes & $5-10$ tonnes \\
\hline Cauliflower & $30,000 \mathrm{lb}$. & $10-15,000 \mathrm{lb}$. \\
\hline French bean & $42,000 \mathrm{lb}$. of pods & - \\
\hline for eating & \\
\hline Lettuce & $21,000 \mathrm{lb}$. & $9,000 \mathrm{lb}$. \\
\hline Lady's finger & $19,000 \mathrm{lb}$. & $5-8,000 \mathrm{lb}$. \\
\hline Cucumber & $28,000 \mathrm{lb}$. & $7,000 \mathrm{lb}$. \\
\hline
\end{tabular}

Table- 3: Vegetable production under soil-less culture in India [5]

\begin{tabular}{|l|l|}
\hline Vegetables & Production $\left(\mathbf{g} / \mathbf{m}^{2} /\right.$ day $)$ \\
\hline Carrot & 56.5 \\
\hline Cucumber & 226 \\
\hline Garlic & 57 \\
\hline Ginger & 57 \\
\hline Leek & 57 \\
\hline Green Bean & 113 \\
\hline Lettuce & 226 \\
\hline Onion & 56.5 \\
\hline Peapod & 113 \\
\hline Potato & 56.5 \\
\hline Salad greens & 226 \\
\hline Tomato & 113 \\
\hline Greens & 113 \\
\hline
\end{tabular}

Application of pesticides is generally avoided under hydroponics system. With reduced pest problems and constant feeding of nutrients to the roots, productivity in hydroponics is high, despite limited plant growth by the low levels of carbondi-oxide in the atmosphere, or limited light[5]. To increase yield further, some sealed greenhouses inject carbon-di-oxide into their environment to help growth ( $\mathrm{CO} 2$ enrichment), or add lights to lengthen the day, control vegetative growth etc.

\section{SUPPLY OF NUTRIENTS TO THE PLANTS}

In hydroponics, because of limited nutrient-buffering capacity of the system and the ability to make rapid changes, careful monitoring of the system in necessary[5]. Two aspects of nutrition need to be considered: the supply of nutrients from the nutrient delivery system and the plant nutrient response. For most common crop plants critical levels for most nutrients have been determined. Sources of nutrient elements with their characteristics are given in table 4.

\section{Sources of nutrient elements}

Table -4: Sources of nutrient elements with their characteristics [5]

\begin{tabular}{|l|l|l|}
\hline Source & Element & Characteristics \\
\hline $\begin{array}{l}\text { Potassium nitrate } \\
\mathrm{KNO}_{3}\end{array}$ & $\mathrm{~N}, \mathrm{~K}$ & Very soluble salt \\
\hline $\begin{array}{l}\text { Potassium phosphate } \\
\text { monobasic } \mathrm{KH}_{2} \mathrm{PO}_{4}\end{array}$ & $\mathrm{P}, \mathrm{K}$ & $\begin{array}{l}\text { Corrects } \\
\text { phosphorus } \\
\text { deficiency }\end{array}$ \\
\hline $\begin{array}{l}\text { Magnesium sulfate } \\
\mathrm{MgSO}_{4}\end{array}$ & $\mathrm{~S}, \mathrm{Mg}$ & $\begin{array}{l}\text { Cheap, highly } \\
\text { soluble, pure salt }\end{array}$ \\
\hline Iron chelate & $\mathrm{Fe} \mathrm{Cit}$ & $\begin{array}{l}\text { Best sources of } \\
\text { iron }\end{array}$ \\
\hline Boric acid $\mathrm{H}_{3} \mathrm{BO}_{3}$ & $\mathrm{~B}$ & $\begin{array}{l}\text { Best source of } \\
\text { boron }\end{array}$ \\
\hline $\begin{array}{l}\text { Calcium nitrate } \\
\text { Ca( }\left(\mathrm{NO}_{3}\right)_{2}\end{array}$ & $\mathrm{~N}, \mathrm{Ca}$ & Very soluble salt \\
\hline
\end{tabular}

The frequency and volume of the nutrient solution applied depends on the type of substrate used (volume and physicalchemical characteristics), the crop (species and stage of development), the size of the container, the crop and irrigation systems used and the prevailing climatic conditions. Plants should be fed daily[5]. The best time to administer the nutrient solution is between 6.00 and $8.00 \mathrm{am}$, though water requirements will vary considerably throughout the day, and from one day to another. The solution should be applied to the roots, trying to avoid wetting the leaves to prevent damage and the appearance of diseases. Under no circumstances should plants be allowed to suffer from water stress, as this will affect their final yield[6]. It is generally recommended that you apply only water to the plants once a week, in order to flush away any excess salts that have remained. Use double the amount of water normally applied, but without adding nutrients. Between 20 and $50 \%$ of the solution should be drained-off to prevent the accumulation of toxic ions and an excessive increase of electrical conductivity in the root area[5]. The excess nutrient solution that is drained away from containers during daily watering can be reused in the next watering. At the end of the week, this liquid can be discarded. Flow chart of supply of nutrients to the plants under soil-less culture has been depicted below: 


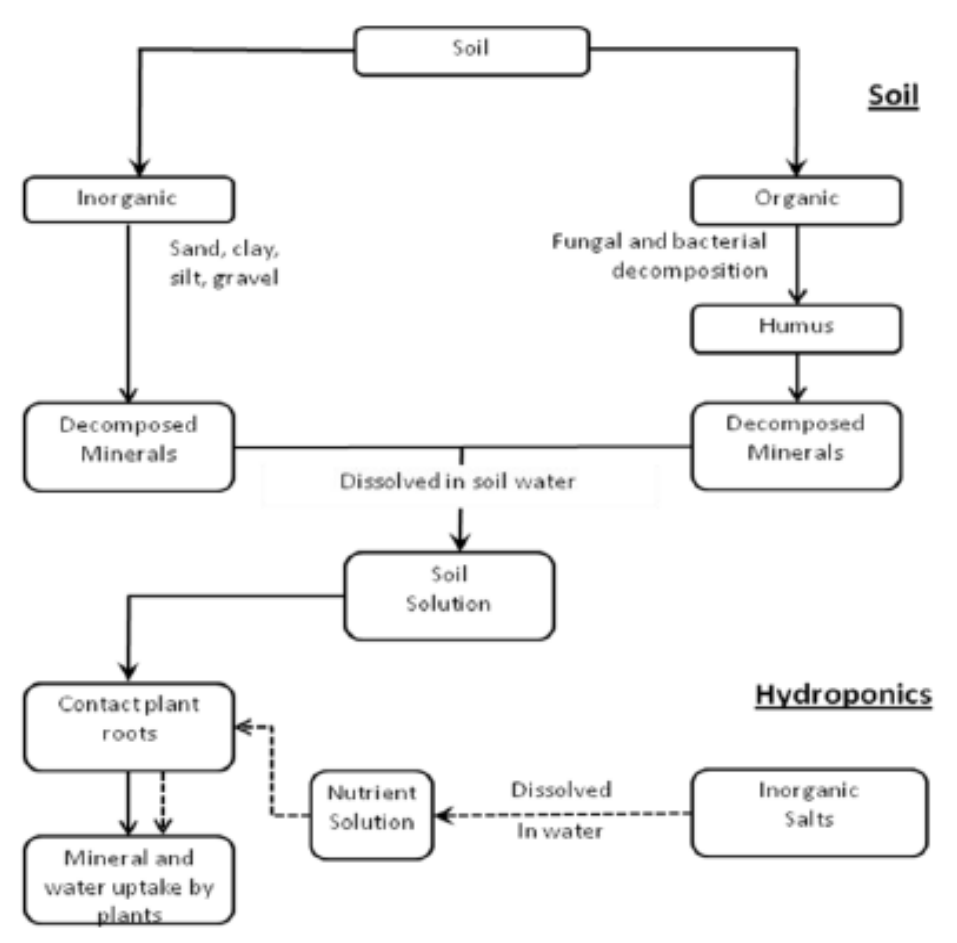

Fig- 4: Flow chart of supply of nutrients to the plants (http://cpamoneyshop.com/make-money-online2/hydroponics)

\section{DESIRABLE pH RANGE OF NUTRIENT SOLUTIONS}

In hydroponic systems, $\mathrm{pH}$ is constantly changing as the plant grows. Changes in $\mathrm{pH}$ of less than 0.1 unit are not significant[6]. Thus $\mathrm{pH}$ control is a necessity in hydroponic solutions. The $\mathrm{pH}$ range of 5.5 to 6.5 is optimal for the availability of nutrients from most nutrient solutions for most species, but species differ significantly and several can grow well outside of this range[6].

\section{CONTROL OF CONTAMINANTS}

Maintenance of sterile root-zone environment is essential to have good plant vigour under soil-less culture. It is extremely difficult to achieve and critical to minimize population of plant pathogens in the root zone[7]. Commonly encountered disease in hydroponic solution is wilt, caused by Fusarium and Verticillum. Species of Pythium and Phytophthora destroys all but the main roots. No effective fungicides are there which can be safely used in hydroponics[8]. Only Metalaxyl has been found highly effective for control of Pythium on vegetable crops, but it is not registered for the use. Heat treatment of nutrient solution has also been found effective in keeping the root-zone free of pathogens[7]. Root death of tomatoes by Pythium was overcome by heating nutrient solutions at 20$22 \mathrm{oC}$. In aeroponic system with heated nutrient solution, the roots of ginger plants matured faster and produced slightly higher fresh rhizome yields than plants in the same medium without bottom heat[5].

\section{ADVANTAGES OF SOIL-LESS CULTURE}

There are many advantages of growing plants under soil-less culture over soil-based culture[8]. These gardens produce the healthiest crops with high yields and are consistently reliable; gardening is clean and extremely easy, requiring very little effort[9]. Here nutrients are fed directly to the roots, as a result plants grow faster with smaller roots, plants may be grown closer, and only $1 / 5$ th of overall space and $1 / 20$ th of total water is needed to grow plants under soil-less culture in comparison to soil-based culture[9]. There is no chance of soil-borne insect pest, disease attack or weed infestation too. Overall soil-less culture provides efficient nutrient regulation, higher density planting, and leading to increased yield per acre along with better quality of the produce. It is also effective for the regions of the World having scarcity of arable or fertile land for agriculture[10].

\section{LIMITATIONS OF SOIL-LESS CULTURE}

Despite of many advantages, soil-less culture has some limitations[10]. Application on commercial scale requires technical knowledge and high initial investment, though returns are high[10]. Considering the high cost, the soil-less culture is limited to high value crops. Great care is required with respect to plant health control. Finally energy inputs are necessary to run the system[11].

\section{FUTURE SCOPE OF THIS TECHNOLOGY}

Hydroponics is the fastest growing sector of agriculture, and it could very well dominate food production in the future [3]. As population increases and arable land declines due to poor land management, people will turn to new technologies like hydroponics and aeroponics to create additional channels of crop production[4]. To get a glimpse of the future of hydroponics, we need only to examine some of the early adopters of this science[5]. In Tokyo, land is extremely valuable due to the surging population. To feed the citizens while preserving valuable land mass, the country has turned to hydroponic rice production[6]. The rice is harvested in underground vaults without the use of soil. Because the environment is perfectly controlled, four cycles of harvest can be performed annually, instead of the traditional single harvest[12].

Hydroponics also has been used successfully in Israel which has a dry and arid climate[11]. A company called Organitech has been growing crops in 40-foot (12.19-meter) long shipping containers, using hydroponic systems. They grow large quantities of berries, citrus fruits and bananas, all of which couldn't normally be grown in Israel's climate[11]. The hydroponics techniques produce a yield 1,000 times greater 
than the same sized area of land could produce annually[12]. Best of all, the process is completely automated, controlled by robots using an assembly line-type system, such as those used in manufacturing plants. The shipping containers are then transported throughout the country[5].

There has already been a great deal of buzz throughout the scientific community for the potential to use hydroponics in third world countries, where water supplies are limited[3-6]. Though the upfront capital costs of setting up hydroponics systems is currently a barrier but in the long-run, as with all technology, costs will decline, making this option much more feasible[5-7]. Hydroponics has the ability to feed millions in areas of Africa and Asia, where both water and crops are scarce.

Hydroponics also will be important to the future of the space program[12]. NASA has extensive hydroponics research plans in place, which will benefit current space exploration, as well as future, long-term colonization of Mars or the Moon[11]. As we haven't yet found soil that can support life in space, and the logistics of transporting soil via the space shuttles seems impractical, hydroponics could be key to the future of space exploration[11]. The benefits of hydroponics in space are twofold: It offers the potential for a larger variety of food, and it provides a biological aspect, called a bio-regenerative life support system[12]. This simply means that as the plants grow, they will absorb carbon-di-oxide and stale air and provide renewed oxygen through the plant's natural growing process. This is important for long-range habitation of both the space stations and other planets[5].

\section{CONCLUSIONS}

The industry is expected to grow exponentially also in future, as conditions of soil growing is becoming difficult. Specially, in a country like India, where urban concrete conglomerate is growing each day, there is no option but adopting soil-less culture to help improve the yield and quality of the produce so that we can ensure food security of our country. However, Government intervention and Research Institute interest can propel the use of this technology.

\section{REFERENCES}

[1]. Ellis, N.K., Jensen, M., Larsen, J. and Oebker, N., "Nutriculture Systems-Growing Plants Without Soil". Station Bulletin No. 44. Purdue University, Lafayette, Indiana.( 1974)

[2]. Beibel, J.P. , "Hydroponics -The Science of Growing Crops Without Soil”. Florida Department of Agric. Bull. p. 180,( 1960.)

[3]. Butler, J.D. and Oebker, N.F. ,"Hydroponics as a Hobby- Growing Plants Without Soil". Circular 844. Information Office, College of Agriculture, University of Illinois, Urbana, IL 61801.( 2006.)
[4]. Maharana, L. and Koul, D.N.. The emergence of Hydroponics. Yojana (June). 55 : 39-40.( 2011)

[5]. Singh, S. and Singh, B. S.. "Hydroponics - A technique for cultivation of vegetables and medicinal plants". In. Proceedings of 4th Global conference on -Horticulture for Food, Nutrition and Livelih,ood Options\| Bhubaneshwar, Odisha, India. p.220. (2012)

[6]. De Kreij C; Voogt W; Baas R (1999). Nutrient solutions and water quality for soilless cultures. Research Station for Floriculture and Glasshouse Vegetables (PBG), Naaldwijk, The Netherlands, Brochure 196

[7]. Raviv M; Krasnovsky A; Medina S; Reuveni R (1998). Assessment of various control strategies for recirculation of greenhouse effluents under semi-arid conditions. Journal of Horticultural Science and Biotechnology, 73(4), 485-491 [8]. Savvas D (2002). Nutrient solution recycling in hydroponics. In: HydroponicProduc tion of Vegetables and Ornamentals (Savvas D; Passam H C, eds), pp 299-343. Embryo Publications, Athens, Greece

[9]. Silberbush M; Ben-Asher J (2001). Simulation study of nutrient uptake by plants from soilless cultures as affected by salinity buildup and transpiration. Plant and Soil, 233, 59-69

[10]. Sonneveld C (2000). Effects of salinity on substrate grown vegetables and ornamentals in greenhouse horticulture. PhDThesis, University of Wageningen, The Netherlands

[11]. Van Os E A; Gieling Th H; Ruijs M N A (2002). Equipment for hydroponicinstallations. In: HydroponicProduc tion of Vegetables and Ornamentals (Savvas D; Passam H C, eds),pp 103-141. Embryo Publications, Athens, Greece

\section{BIOGRAPHIES:}

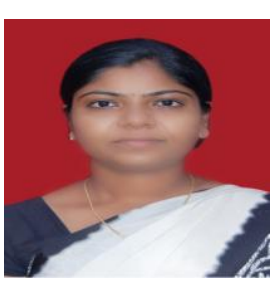

\section{Mamta D. Sardare}

Assistant Professor, MIT Academy of Engineering Alandi Pune, Maharashtra, India, mamtasardare@gmail.com

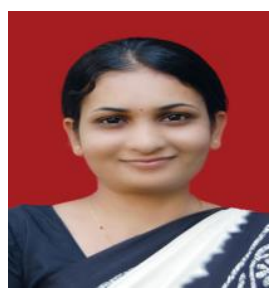

Shraddha V. Admane

Technical Assistant, MIT Academy of Engineering Alandi Pune, Maharashtra, India, shraddhaadmane@gmail.com 